\title{
SPARC Oppositely Regulates Inflammation and Fibrosis in Bleomycin-Induced Lung Damage
}

\author{
Sabina Sangaletti, ${ }^{*}$ Claudio Tripodo, ${ }^{\dagger}$ \\ Barbara Cappetti, ${ }^{*}$ Patrizia Casalini, ${ }^{*}$ \\ Claudia Chiodoni, ${ }^{*}$ Silvia Piconese, ${ }^{*}$ \\ Alessandra Santangelo, ${ }^{*}$ Mariella Parenza, ${ }^{*}$ \\ Ivano Arioli, ${ }^{*}$ Silvia Miotti, ${ }^{*}$ and Mario P. Colombo* \\ From the Molecular Immunology Unit* and the Molecular \\ Targets Unit, ${ }^{\ddagger}$ Department of Experimental Oncology and \\ Molecular Medicine, Fondazione IRCCS Istituto Nazionale \\ Tumori, Milan; the Department of Health Sciences, ${ }^{\dagger}$ Patbology \\ Section, Università degli Studi di Palermo, Palermo, Italy
}

Fibrosis results from inflammatory tissue damage and impaired regeneration. In the context of bleomycininduced pulmonary fibrosis, we demonstrated that the matricellular protein termed secreted protein acidic and rich in cysteine (SPARC) distinctly regulates inflammation and collagen deposition, depending on its cellular origin. Reciprocal Sparc $^{-/-}$and wild-type (WT) bone marrow chimeras revealed that SPARC expression in host fibroblasts is required and sufficient to induce collagen fibrosis in a proper inflammatory environment. Accordingly, Sparc $^{-1-}$ $>$ WT chimeras showed exacerbated inflammation and fibrosis due to the inability of $S_{p a r c}{ }^{-/}$macrophages to down-regulate tumor necrosis factor production because of impaired responses to tumor growth factor- $\beta$. Hence, the use of bone marrow cells expressing a dominant-negative form of tumor growth factor- $\beta$ receptor type II under the monocytespecific CD68 promoter, as a decoy, phenocopied Sparc $^{-/-}$donor chimeras. Our results point to an unexpected dual role of SPARC in oppositely influencing the outcome of fibrosis. (Am J Patbol 2011, 179:3000-3010; DOI: 10.1016/j.ajpath.2011.08.027)

Tissue remodeling and repair are characterized by epithelial to mesenchymal transition. Excessive inflammatory responses in tissues may lead to prominent cell destruction that exceeds the intrinsic regenerative potential of the parenchyma stem cell reservoir. Subsequently, fibrotic tissue can occupy the area of impaired regeneration. Although this form of repair does not replace the tissue or organ function (eg, myocardial scarring after infarction), the process is, in most cases, controlled and its regulation dependent on the resolution of the underlying inflammatory spur. The matricellular glycoprotein termed secreted protein acidic and rich in cysteine (SPARC) has a key role in extracellular matrix (ECM) assembly and molding. Consistently, SPARC has been implicated in the pathogenesis of several fibrotic disorders, such as adipose tissue fibrosis, ${ }^{1}$ hepatic fibrosis, ${ }^{2,3}$ lung fibrosis, ${ }^{4}$ and scleroderma. ${ }^{5}$ This notion comes from data generated in Sparc ${ }^{-1-}$ mice or gene-silencing strategies in models of skin, liver, and pulmonary fibrosis. Accordingly, Sparc ${ }^{-1-}$ mice were protected from bleomycin-induced pulmonary fibrosis ${ }^{6}$ and adenoviral-mediated inhibition of SPARC, or intratracheal instillation of small-interfering RNA attenuated pulmonary fibrosis in rats and mice, respectively. ${ }^{7,8}$ In this setting, SPARC function is mainly linked to the regulation of tumor growth factor- $\beta 1$ (TGF- $\beta 1$ ) signaling and collagen production by fibroblasts. Nevertheless, contrasting results show increased lung fibrosis in Sparc ${ }^{-1-}$ mice after bleomycin administration, ${ }^{9}$ a condition that was associated with an increased inflammatory cell infiltration. We have previously shown that the absence of SPARC exacerbated contact hypersensitivity ${ }^{10}$ and favored leukocyte infiltration into the tumor parenchyma. ${ }^{11}$ Said and colleagues reported that SPARC is able to ameliorate tumor-associated inflammation in the setting of ovarian cancer. ${ }^{12}$ These findings suggest that SPARC may play contrasting roles, depending on its cellular source and the pathological setting, by either promoting or attenuating the inflammatory damage and causing parenchymal fibrosis.

Supported by grants from Cariplo Foundation, Italian Association for Cancer Research (AIRC), and the Italian Ministry of Health, Labor and Social Welfare: $5 \%$ donations under the Scientific Directorate's Special Project on Lung Cancer.

Accepted for publication August 18, 2011.

S.S. and C.T. contributed equally to this work.

Supplemental material for this article can be found at http://ajp. amjpathol.org or at doi: 10.1016/j.ajpath.2011.08.027.

Address reprint requests to Mario P. Colombo, Ph.D., Molecular Immunology Unit, Department of Experimental Oncology and Molecular Medicine, Fondazione IRCCS Istituto Nazionale Tumori Via Amadeo 42, 20133 Milano, Italy. E-mail: mario.colombo@istitutotumori.mi.it. 
The aim of this work was to dissect the effector and regulatory role of SPARC in fibrotic diseases. To this end, we used the well-characterized bleomycin-induced pulmonary fibrosis model in mice, which recapitulates the disease observed in the clinical setting of patients receiving bleomycin as a chemotherapeutic agent. ${ }^{13}$ This prototypical mouse model is used for studying inflammationengendered organ fibrosis and has already generated contradictory results when Sparc ${ }^{-1-}$ mice were used. ${ }^{6,9}$

We show that SPARC, in the context of pulmonary fibrosis, exerts different functions, depending on the cell of origin. Particularly, through bone marrow transplantation (BMT) experiments, we demonstrated that SPARC produced by bone marrow-derived leukocytes limits fibrosis by reducing the extent of inflammation, whereas SPARC from fibroblasts or fibrocytes sustains fibrosis, promoting collagen assembly. We also show that the anti-inflammatory activity of SPARC is dependent on its regulation of TGF- $\beta$ signaling on macrophages.

To our knowledge, this is the first demonstration of the dual function of the matricellular protein SPARC in the regulation of tissue stroma homeostasis. Our observation adds a new insight into the combined and opposite antiinflammatory and profibrotic effect of TGF- $\beta$.

\section{Materials and Methods}

\section{Animals}

$\mathrm{BALB} / \mathrm{CAnNCrl}$ mice, 8 to 10 weeks old, were purchased from Charles River Laboratories (Calco, Italy). CNCr.129S(B6)-Sparc ${ }^{\text {tm1Hwe }}$ mice were developed in our institute by backcrossing B6;129S-Sparc ${ }^{\text {tm1Hwe }}$ (provided by Dr. Chin Howe, Wistar Institute, Philadelphia, $\mathrm{PA})$ to $\mathrm{BALB} / \mathrm{CAnNCrl}$ mice for 12 generations before intercrossing them. ${ }^{11}$ Thy $11^{a}$ mice, on unspecified BALB/C background (originally provided by Dr. Hyam Levitsky, Johns Hopkins University, Baltimore, MD) were crossed to $\mathrm{BALB} / \mathrm{CAnNCrl}$ mice at least for 6 generations. Animal experiments were authorized by the Institutional Ethical Committee for Animal Use. Mice were housed in filtered top caging, and room sentinels were checked for pathogens every 6 months by Charles River Laboratories staff. Viral pathogens that are excluded are as follows: mouse hepatitis virus), mouse parvovirus, mouse encephalomyelitis virus, pneumonia virus of mice, sendai virus, reovirus-3, Hantaan virus, lymphocytic choriomeningitis virus), mouse adenovirus, minute virus of mice, rotavirus, polyomavirus, $\mathrm{K}$ virus, ectromelia virus, mouse thymic virus, and mouse cytomegalovirus. Excluded bacterial agents are as follows: Mycoplasma pulmonis, cilia-associate respiratory bacillus, Citrobacter rodentium, and Salmonella sp. In addition, Helicobacter spp. and mouse norovirus are also tested in sentinels but are not excluded agents.

\section{Generation of Bone Marrow Chimeras}

Chimeric Sparc ${ }^{-1-}\left(\right.$ Thy $\left.1^{b}\right)>$ wild type (WT) $\left(\right.$ Thy $\left.1^{a}\right)$ and WT $\left(\right.$ Thy $\left.1^{a}\right)>$ Sparc ${ }^{-1-}\left(\right.$ Thy $\left.1^{b}\right)$ mice (hereafter referred to as $\mathrm{WT}>\mathrm{KO}$ and $\mathrm{KO}>\mathrm{WT}$ ) were obtained as previously described. ${ }^{11}$ Engraftment was verified 6 to 8 weeks after
BMT by staining peripheral blood mononuclear cells with fluorescein isothiocyanate-conjugated anti-mouse Thy $1^{\text {a }}$ (CD90.1; Becton Dickinson, Franklin Lakes, NJ) and phycoerythrin-conjugated anti-mouse Thy $1^{\mathrm{b}}$ (CD90.2, Becton Dickinson), as well as isotype control fluorescein isothiocyanate- and phycoerythrin-conjugated mouse IgG2a. Bone marrow cells expressing the dominant negative form of TGF- $\beta$ receptor II (TGF- $\beta$ RII) under the monocyte-specific CD68 promoter have been obtained by infection with the lentiviral CD68DNTGFBRII vector (see below).

\section{Generation of WT and Sparc ${ }^{-1-}$ Fibroblasts}

Dermal fibroblasts from newborn mouse skin were prepared according to the method of Regnier et al. ${ }^{14}$ The dorsal skin from 1- to 3-day-old mice was incubated in $0.2 \%$ trypsin in PBS at $37^{\circ} \mathrm{C}$ for 1 hour. Dermal fibroblasts were produced by digestion of muscle and dermis in HBSS solution containing $0.1 \%$ collagenase and $0.1 \%$ hyaluronidase, followed by filtration, centrifugation, and resuspension. Viable cells were plated at 2 to $5 \times 10^{6}$ cells $/ \mathrm{mL}$ in 50-mm-diameter plastic Petri dishes containing Dulbecco's modified Eagle's medium were supplemented with $10 \%$ fetal calf serum. Fibroblasts from both WT and Sparc ${ }^{-1-}$ mice were nontumorigenic when injected into BALB/c mice. To assess fibroblast proliferation in vitro, we used spectrophotometric assay, ${ }^{15}$ using $1 \%$ methylene blue dye in $0.01 \mathrm{M}$ borate buffer, $\mathrm{pH} 8.5$, according to Colombo et al. ${ }^{16}$ Fibroblast migration toward bovine fibronectin (Sigma-Aldrich, St. Louis, MO) was evaluated by using Transwell supports (Corning, Lowell, MA) as previously described. ${ }^{17}$

\section{Generation of WT and Sparc ${ }^{-1-}$ Macrophages}

WT and Sparc ${ }^{-1-}$ macrophages were obtained from bone marrow precursors by plating them in the presence of $10 \mathrm{ng} / \mathrm{mL}$ of granulocyte-macrophage colony-stimulating factor and $10 \mathrm{ng} / \mathrm{mL}$ of $\mathrm{IL}-4$. On days 2, 4, and 6, floating cells consisting mainly of dendritic cells were eliminated and supplemented medium was replaced. On day 7 , up to $90 \%$ of the adherent population consisted of macrophages as determined by flow cytometry analysis using the F4/80-specific monoclonal antibody (CaltagMedsystems, Buckingham, UK).

\section{Lentiviral Vector Construction}

For the generation of CD68DNTGFBRII vector, DNA was obtained from transgenic mice expressing DNTGFBRII under the human CD2 promoter (gift of Ronald E. Gress, National Institutes of Health, Bethesda, MD). By PCR, the DNTGFBRII cassette was amplified and restriction sites for Agel and Sall were added at $5^{\prime}$ and $3^{\prime}$ ends (forward primer: 5'-TTACCGGTAGAAGTCCCAACCCAGCTTT-3'; reverse primer: 5'-AATTGTCGACATGGCTGAGTTCGAAGA-3'). The PCR product was inserted into pRRLsinCD68GFP-hPGK- NGFR-WPRE lentiviral vector by Agel/Sall cloning substituting the GFP with the DNTGFBRII sequence. 


\section{In Vivo Treatments}

For bleomycin treatment, animals were anesthetized with i.p. injection of ketamine $(100 \mathrm{mg} / \mathrm{kg})$ and xylazine (5 $\mathrm{mg} / \mathrm{kg}$ ). The trachea was exposed in sterile conditions, and $0.15 \mathrm{U}$ per mouse of $20 \mathrm{~g}$ of bleomycin or saline solution were instilled in $50 \mu \mathrm{L}$ of final volume. The skin incision was closed and mice allowed to recover under a warming lamp. Mice were sacrificed 16 days after bleomycin instillation and their lungs removed for histologic analysis, fluorescence activated cell sorter (FACS) analysis, or measurement of the hydroxyproline (HP) content. For in vivo antibody treatment, mice were administered $200 \mu \mathrm{g}$ of rat anti-mouse tumor necrosis factor (TNF) V1q (provided by Daniela Männel, University of Regensburg, Regensburg, Germany) every 3 days, starting 1 day before bleomycin instillation. Experiments requiring V1q administration in $\mathrm{KO}>\mathrm{WT}$ chimeric mice have been performed on a total of 20 mice in two consecutive experiments. In each experiment, six mice were treated with the antibody and four mice with saline as control.

\section{Lung HP Content}

Lung HP content was determined spectrophotometrically according to Kivirriko et al. ${ }^{18}$ Briefly, lungs were homogenized in a solution of trichloroacetic acid and centrifuged for 10 minutes at $4000 \times g$. The pellet was washed and hydrolyzed for 16 hours in $\mathrm{HCl}(6 \mathrm{~N})$ at $100^{\circ} \mathrm{C}$. The $\mathrm{HP}$ content was assessed colorimetrically at $561 \mathrm{~nm}$ with p-dimethylaminobenzaldehyde, quantified in micrograms and normalized for lung weight. Data are shown as total HP content.

\section{Histopathologic Analysis}

To allow for morphologic analysis, lungs were fixed in situ by intratracheal injection of $10 \%$ neutral buffered formalin after mice sacrifice. The trachea was cannulated and the lungs fixed in situ with $10 \%$ formalin at a constant rate. The optimal instilled volume for mouse lungs was $0.3 \mathrm{~mL}$ for $20 \mathrm{~g}$ of weight. ${ }^{19}$ Lungs were removed, maintained 24 hours in formalin, and then embedded in paraffin. Sections 3 to $4 \mu \mathrm{m}$ thick were cut from paraffin blocks and stained with H\&E, Masson's trichrome, and periodic acidSchiff stain. Grading of the tissue damage was performed by a semiquantitative scoring system based on the following variables: thickening of the alveolar wall, extent of the interstitial inflammatory infiltrate, extent of fibroblast proliferation, extent of epithelial proliferation, extracellular collagen deposition, intracellular collagen amount, and overall extent of the parenchymal damage. Each variable was scored from 0 (normal samples) to 3, according to the severity of changes. The overall histologic damage score was calculated by summing the mean scores of each variable. All of the samples were analyzed by two of the authors with specific training in mouse pathology (S.S. and C.T.) in a blinded fashion under a Leica DM3000 optical microscope (Leica Microsystems GmbH, Wetzlar, Germany), and microphotographs were col- lected using a Leica DFC320 digital camera (Leica Camera AG, Solms, Germany).

For histopathologic and immunofluorescence (IF) analysis, a total of 35 bleomycin-treated WT and Sparc $^{-1-}$ mice (divided into five experiments) were used. A total of 15 saline-treated mice per group were also analyzed (three mice per experiment). Each experiment was divided as follows: lungs from four bleomycin-treated mice were fixed in formalin and those from three mice embedded in optimal cutting temperature (OCT) compound (Sakura, Torrance, CA) and lungs from two saline-treated mice were fixed in formalin and those from one mouse in OCT as control.

Histopathologic analysis and IF analysis on bone marrow chimeras were similarly performed on 30 bleomycintreated and 15 saline-treated mice per group.

Histopathologic analysis on bleomycin-treated WT mice transplanted with bone marrow cells expressing the dominant negative form of TGF- $\beta$ RII under the monocytespecific CD68 promoter has been performed on a total of 10 mice, from two independent experiments.

The following antibodies have been used for IF and/or immunohistochemistry (IHC): polyclonal goat anti-SPARC antibody (AF942; R\&D, Minneapolis, MN), monoclonal antibody to CD90.1 and CD90.2 (Becton Dickinson), monoclonal antibody to CD68 (Hycult Biotech, Plymouth Meeting, PA), monoclonal antibody to prosurfactant protein C (Millipore, Billerica, MA), polyclonal rabbit to antifibroblast specific protein 1 (FSP1) (Abcam, Cambridge, MA), anti-collagen types I and IV (Millipore), polyclonal antibody to $\alpha$-smooth muscle actin ( $\alpha$-SMA; Sigma-Aldrich), and monoclonal rat anti-mouse panreticular fibroblast marker (clone ER-TR7; Cedarlane, Burlington, NC).

\section{Western Blot Analysis}

WT and Sparc ${ }^{-1-}$ fibroblasts were washed twice with cold PBS buffer and lysed in the RIPA buffer (1\% NP-40, $0.5 \%$ sodium deoxycholate, $0.1 \%$ SDS) added with a protease inhibitor cocktail (Roche, Milan, Italy). Cell lysates were microcentrifuged at 14,000 $\times g$ for 20 minutes at $4^{\circ} \mathrm{C}$ and supernatants collected and stored at $-80^{\circ} \mathrm{C}$. Protein concentration in each sample was determined by the BCATM Protein Assay kit (Thermo Fisher Scientific, Waltham, MA). Cell lysates containing equal amounts of protein $(25 \mu \mathrm{g})$ were analyzed by SDS-PAGE on precasted minigels (Invitrogen, Carlsbad, CA) and proteins transferred to a nitrocellulose membrane (GE Healthcare, Waukesha, WI). Nonspecific binding sites were blocked in 5\% nonfat dry milk in Tris-buffered saline-Tween (100 $\mathrm{mmol} / \mathrm{L}$ Tris, $0.9 \% \mathrm{NaCl}, \mathrm{pH} 7.5,0.1 \%$ Tween 20 ) solution. Membrane was incubated overnight at $4^{\circ} \mathrm{C}$ with a polyclonal rabbit anti-collagen type I antibody (1:600; Millipore) or a polyclonal monoclonal antibody to SPARC (R\&D), washed three times each for 5 minutes with Trisbuffered saline containing $0.1 \%$ Tween 20 , and then incubated with horseradish peroxidase-conjugated antibody (1:2500; Zymed, San Francisco, CA) for 1 hour at room temperature. After washing, blots were developed with an enhanced chemiluminescence system (ECL-plus; GE Healthcare). 
For Western blot analysis of TNF, 20- $\mu \mathrm{m}$ cryostat sections were obtained from snap frozen whole-lung tissue and collected in 1.5-mL tubes. Sections were then homogenized in ice-cold lysis buffer (RIPA buffer without urea). Equal amounts of total protein $(25 \mu \mathrm{g})$ were loaded in each lane. Blots were blocked and incubated overnight at $4^{\circ} \mathrm{C}$ with a monoclonal rat anti-mouse TNF antibody (Becton Dickinson). Protein bands were quantified by Image Quant 5.2 (GE Healthcare, Milan, Italy).

\section{IF and Confocal Microscopy}

Frozen cryostat sections were fixed in acetone, dried, and incubated 20 minutes with a blocking 10\% fetal calf serum solution. Sections where then incubated 1 hour with the primary antibody, washed, and incubated 40 minutes with Alexa Fluor-conjugated secondary antibody. For IF analysis of intracellular antigens, a permeabilization step in $0.1 \%$ Tween and $1 \%$ fetal calf serum solution was performed. Slides were analyzed with a confocal microscopy (Microradiance 2000; Bio-Rad Laboratories, Hercules, CA) equipped with $\operatorname{Ar}(488 \mathrm{~nm})$ and $\mathrm{HeNe}(543 \mathrm{~nm})$ lasers. Confocal images $(512 \times 512$ pixels) were obtained using a $\times 60$ oil immersion lens and analyzed using ImagePro 6.3 software. Reported images represent extended depth of field from 15 to 16 frames in stack (0.5- $\mu \mathrm{m}$ step); a focus region was selected for maximum intensity. The pinhole diameter was regulated according to the value suggested by the acquisition software to obtain the maximum resolution power.

\section{FACS Analysis}

For FACS analysis cell suspensions were obtained by lung digestion with a collagenase IV/elastase (Worthington Biochemical, Lakewood, $\mathrm{NJ}$ ) solution for 90 minutes at $4^{\circ} \mathrm{C}$. The suspensions were filtered by a cell strainer (BD, Franklin Lakes, NJ), washed, resuspended in $1 \times$ PBS, and stained with the indicated monoclonal antibodies. FACS analysis was performed using BD FACSCalibur or FACSCanto from Becton Dickinson.

\section{Results}

\section{Reduced Fibrosis, Despite High Inflammation, Characterizes the Lungs of Sparc ${ }^{-1-}$ Mice Instilled with Bleomycin}

\begin{abstract}
WT and Sparc ${ }^{-1-}$ mice were treated with bleomycin or saline by intratracheal instillation and sacrificed 16 days later. Histologic analysis and collagen accumulation, evaluated as HP content, showed different outcomes in the two strains. WT mice developed foci of pulmonary fibrosis with an increased number of fibroblasts, interstitial collagen, and alveolar distortion (Figure 1A). In contrast, Sparc ${ }^{-1-}$ mice developed a parenchymal damage characterized by inflammatory infiltration (Figure 1A) that was not associated with foci of fibroblast accumulation or collagen deposition. According to such pictures in Sparc ${ }^{-1-}$ mice, FACS analysis revealed that nearly the $50 \%$ of the cells from bleomycin-treated lungs were $\mathrm{CD}^{+} \mathrm{T}$ cells $(44.82 \% \pm 5.4 \%)$, whereas only $16.53 \% \pm$ $9.4 \%$ were fibroblasts $\left(\alpha-\mathrm{SMA}^{+}\right.$or $\left.\mathrm{FSP} 1^{+}\right)$(see Supple-
\end{abstract}

A

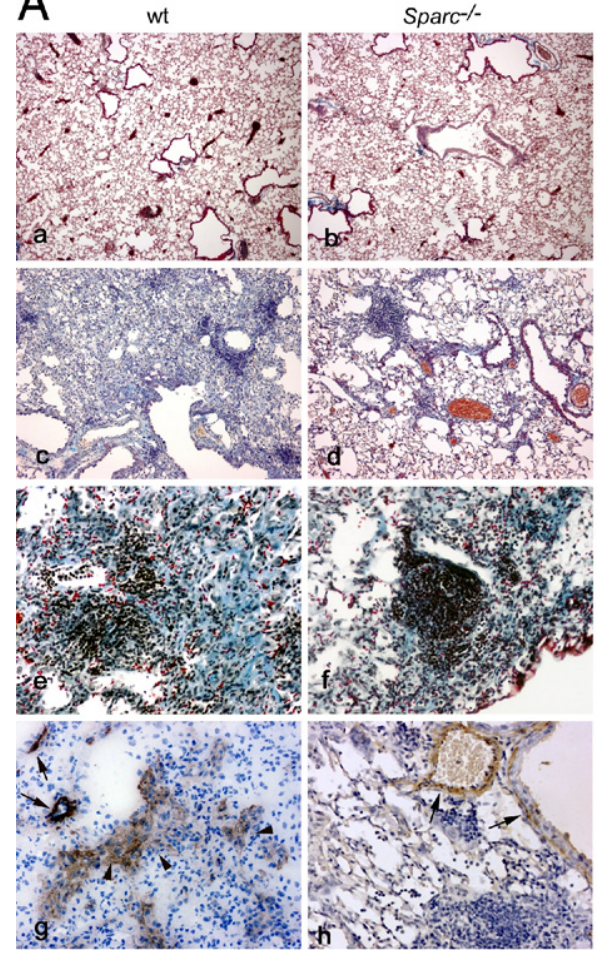

B

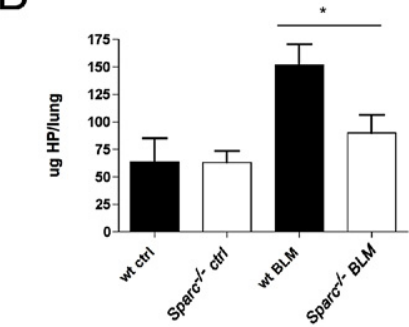

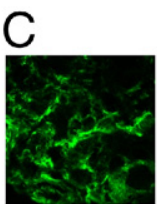

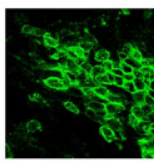

CD45

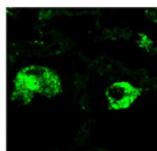

CD68
Pan fibroblast

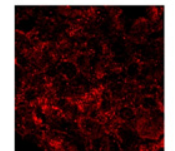

SPARC

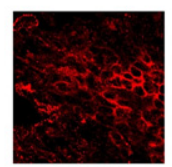

SPARC

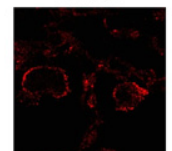

SPARC

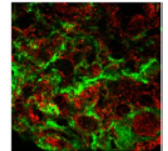

Merge

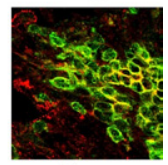

Merge

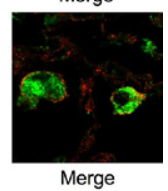

Figure 1. Bleomycin-induced lung injury in WT and Sparc $^{-1-}$ mice. A: Representative photomicrographs of the lung obtained 16 days after bleomycin ( $\mathrm{c}$ and $\mathrm{d}$ : original magnification, $\times 100$; e and $\mathrm{f}$ : original magnification, $\times 200$ ) or saline (a and b: original magnification, $\times 50$ ) instillation. Pictures show conspicuous leukocyte infiltration in Sparc $^{-1-}$ mice (right) associated with milder fibrosis compared with WT mice (left). Lung fibrosis in WT (g) but not Sparc mice (h) is also associated with the presence of $\alpha$-SMA ${ }^{+}$myofibroblasts (arrowhead). In Sparc $^{-/}$lungs $\alpha$-SMA antibody stained only perivascular and peribronchial cells (arrows). B: Lung HP content in bleomycin-treated mice Representative experiments of three experiments performed with seven mice per experiment for bleomycin-treated WT and Sparc mice and four mice per experiment for salinetreated WT and Sparc $^{-/-}$mice. Mean \pm SD values are shown. Bleomycin-treated WT mice had significantly more collagen than Sparc mice (Mann-Whitney $U$-test); ${ }^{*} P=0.0175$. C: Confocal immunofluorescence analysis of SPARC expression in bleomycin-treated WT lungs. In fibrotic areas, SPARC (red signal) expression is associated with fibroblasts (panreticular fibroblast marker monoclonal antibody), infiltrating $\mathrm{CD} 45^{+}$leukocytes, and $\mathrm{CD} 68^{+}$macrophages (original magnification, $\times 630$ ). 
mental Figure S1A at http://ajp.amjpathol.org). On the contrary, the percentage of fibroblast and $\mathrm{CD}^{+}$cells in the lungs from WT mice treated with bleomycin was $41.86 \% \pm 6.31 \%$ and $21.83 \% \pm 2.8 \%$, respectively. Accordingly, IHC confirmed the presence of $\alpha-\mathrm{SMA}^{+}$cells in the fibrotic areas of WT mice, whereas in Sparc ${ }^{-1-}$ mice, antibody to $\alpha$-SMA stained only cells associated with bronchi or blood vessels (Figure 1A). Consistently, HP content was higher in WT than Sparc ${ }^{-1-}$ mice (Figure 1B). These results suggest that in the absence of SPARC fibrosis was reduced, whereas inflammation was apparently increased. Nevertheless, SPARC expression, evaluated by confocal microscopy in bleomycin-treated lungs, was similar in an area of inflammation and fibrosis. Indeed, a SPARC-specific monoclonal antibody stained $\mathrm{CD} 45^{+}$infiltrating leukocytes, $\mathrm{CD}^{+} 8^{+}$macrophages, and fibroblasts and their matrix (Figure 1C). In nonfibrotic and noninflammatory areas, SPARC expression was found in resident $\mathrm{FSP}^{+}{ }^{+}$fibroblasts and was associated with collagen of the basement membrane (see Supplemental Figure S1B at $h$ ttp://ajp.amjpathol.org). The observation of SPARC oppositely affecting fibrosis and inflammation and the consistent detection of SPARC in both fibroblasts and inflammatory cells prompted us to investigate whether SPARC produced by leukocyte or fibroblast had distinct roles in bleomycin-induced lung damage.

\section{Characterization of Fibroblasts in Bleomycin- Induced Pulmonary Fibrosis}

Cross-talk between macrophages and fibroblasts can alternatively exacerbate, suppress, or reverse fibrosis. ${ }^{20}$ Both macrophages and fibroblasts can produce SPARC, and their distinct contribution to fibrosis could be partially investigated by reciprocal BMT between Sparc ${ }^{-1-}$ and WT mice. ${ }^{17}$ This approach, however, is complicated by the different origin of collagen-producing cells, which, besides resident fibroblasts, include fibrocytes ${ }^{21}$ and mesenchymal stem cells of bone marrow origin (BMMSCs). ${ }^{22}$ To evaluate the contribution of bone marrowderived collagen-producing cells in bleomycin-induced fibrosis, we designed ad hoc bone marrow chimeras, which allowed us to distinguish host- and bone marrowderived fibroblasts and fibrocytes on the basis of CXCR4, FSP $1,{ }^{23}$ and CD45 markers (see Supplemental Figure S2 at $h$ ttp://ajp.amjpathol.org). CD45.2 mice were lethally irradiated and transplanted with a CD45.1 bone marrow to distinguish donor and host cells. In such chimeras, after bleomycin treatment, numerous $\mathrm{CXCR} 4^{+}$cells localized mainly into fibrotic areas (Figure 2A), and most were $\mathrm{CD} 45.1^{+}$and therefore of donor origin (Figure 2D). IF analysis (Figure 2B) and flow cytometry (Figure 2D) revealed that among the donor population more then $85 \%$ of $\mathrm{CXCR} 4^{+} / \mathrm{CD} 45.1^{+}$cells were leukocytes (FSP1 ${ }^{-}$, $\alpha-\mathrm{SMA}^{-}$), whereas roughly $6 \%$ of them were fibrocytes $\left(\mathrm{FSP}^{+}{ }^{+}\right.$or $\left.\alpha-\mathrm{SMA}^{+}\right)$. FACS analysis also showed a tiny population $(<2 \%)$ of $\mathrm{CXCR} 4^{+} \mathrm{CD}_{4} 5^{-}$cells that might include BM-MSCs (Figure 2, B and D). This marginal involvement of BM-MSCs in bleomycin-treated lung was confirmed following donor CD90.2 and host
CD90.1 markers on MSCs, identified by the CD146 antigen, ${ }^{24}$ in WT (Thy $\left.1^{\mathrm{b}}, \mathrm{CD} 90.2\right)>\mathrm{WT}$ (Thy $1^{\mathrm{a}}$, CD90.1) bone marrow chimeras (see Supplemental Figure S3 at http://ajp.amjpathol.org).

Donor-derived fibrocytes constituted a small fraction of the total recruited $\mathrm{CXCR} 4{ }^{+}$cells, yet they accounted for approximately $25 \%(28.9 \% \pm 5.9 \%$ in WT and $24.7 \% \pm$ $8.9 \%$ in $\mathrm{KO}$; Figure $2 \mathrm{E}$ ) of the entire $\mathrm{FSP} 1^{+}$population; their relative contribution to fibrosis was evaluated according to their Sparc genotype and the ability to assemble collagen. This finding was relevant in the context of reciprocal BMT between Sparc ${ }^{-1-}$ and WT mice in which collagen assembly by host or donor cells is influenced by their Sparc genotype. Indeed, resident (CXCR4 ${ }^{-}$) fibroblasts and bone marrow-derived (CXCR4 ${ }^{+}$) fibrocytes participated in collagen deposition in WT but not in Sparc $^{-1-}$ mice (Figure 2C). The results indicated that collagen-secreting cells, either resident or bone marrow derived, were impaired in ECM deposition when defective in SPARC. To confirm these data and to assess possible additional defects in proliferation and migration of Sparc ${ }^{-1-}$ fibroblasts compared with WT ones, in vitro experiments were performed (see Supplemental Figure S4 at http://ajp.amjpathol.org). Dermal fibroblasts from Sparc $^{-1-}$ and WT mice were seeded onto polylysinecoated glasses and evaluated for collagen production by IF and Western blot ${ }^{25}$ ) (see Supplemental Figure S4A at http://ajp.amjpathol.org). Despite the similar capacity to produce collagen in WT fibroblasts, Sparc ${ }^{-1-}$ fibroblasts were defective in collagen fiber assembly (see Supplemental Figure S4B at $h t t p: / / a j p . a m j p a t h o l . o r g)$, a process that is crucial to fibrotic disorders. ${ }^{26}$ Western blot analysis revealed that the two collagen type I precursors, a1(I) and a2(I) procollagen, were synthesized without difference in WT and Sparc ${ }^{-1-}$ fibroblasts. Yet, Sparc ${ }^{-1-}$ fibroblasts were defective in the production of the mature form of collagen that is the interstitial collagen deposited in tissue fibrosis. No defects in proliferation and migration were found in Sparc ${ }^{-1-}$ fibroblasts compared with their WT counterparts (see Supplemental Figure S4 at http:// ajp.amjpathol.org). This finding suggested that the milder fibrosis observed in bleomycin-treated Sparc ${ }^{-1-}$ mice could be due to a defective assembly of collagen fibers by Sparc ${ }^{-1-}$ fibroblasts rather than to their impaired recruitment or local expansion.

\section{Dissecting the Role of SPARC from Leukocytes and Fibroblasts in Lung Damage}

The distinct contribution of fibrocytes in fibrosis could be evaluated transplanting Sparc ${ }^{-1-}$ bone marrow into WT mice, a setting in which fibrocytes were defective in collagen assembly. BMT experiments were performed transplanting Thy $1^{a}$ WT mice with bone marrow from Thy $1^{b}$ congenic Sparc ${ }^{-1-}(\mathrm{KO}>\mathrm{WT})$ or WT $(\mathrm{WT}>\mathrm{WT})$ mice. This combination allowed checking the extent of engraftment, which at the time of bleomycin administration (8 weeks after BMT) was more than $95 \%$ donor in circulating $T$ lymphocytes (not shown). Also, lung-infiltrating macrophages in WT $>$ WT but not in KO $>$ WT chimeras showed 
A
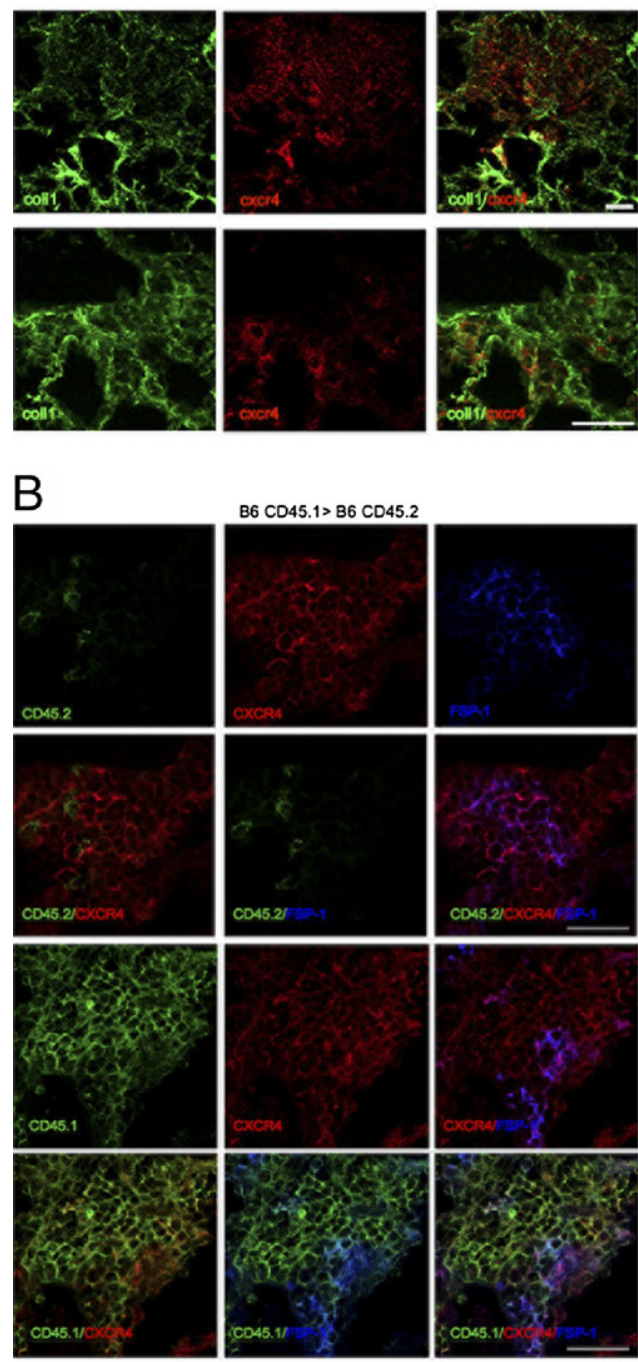

C

wt
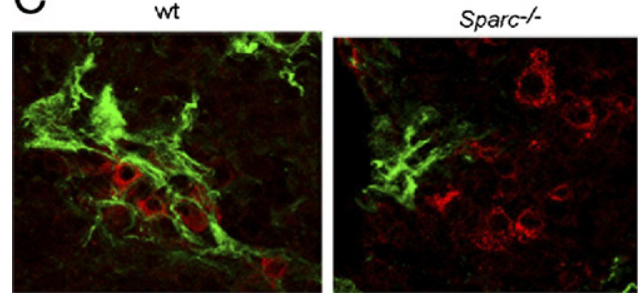

$\mathrm{D}$

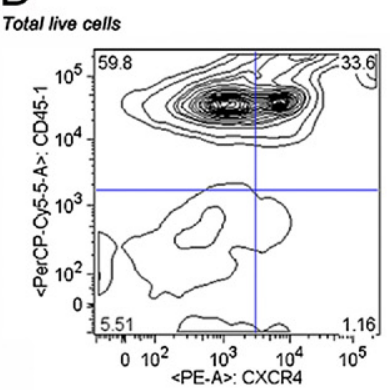

CXCR4+ gate
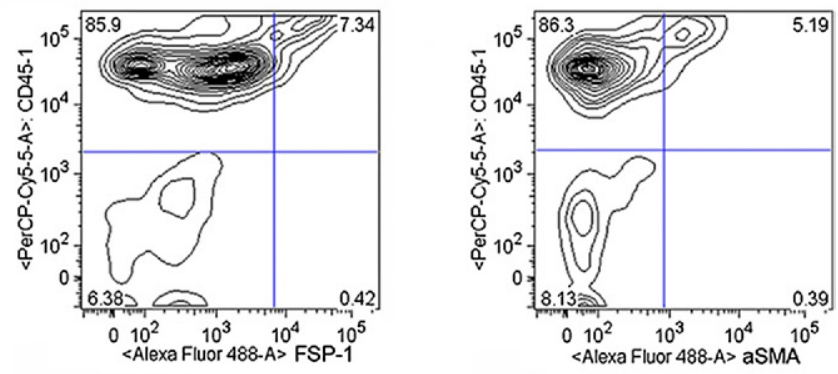

$\mathrm{E}$

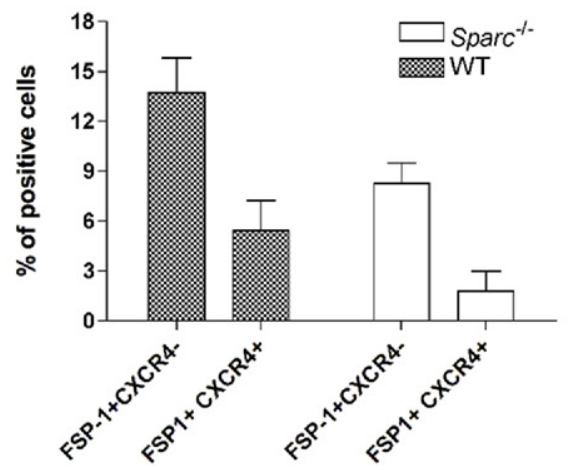

Figure 2. Characterization of fibroblasts in bleomycin-induced fibrosis. A: Confocal microscopy analysis for collagen type I and CXCR4 expression in the lung of bleomycin-treated B6 (CD45.1)>B $6(\mathrm{CD} 45.2)$ mice, showing that $\mathrm{CXCR} 4^{+}$cells are mostly recruited to fibrotic foci. B: In situ IF analysis for FSP1, donor CD45.1, or host CD 45.2 marker on $\mathrm{CXCR}_{4}{ }^{+}$identified the leukocytes and fibrocytes population, confirming the data (scale bar $=25 \mu \mathrm{m})$. C: Confocal microscopy analysis revealed that in WT but not Sparc ${ }^{-1-}$ lungs, CXCR4 ${ }^{+}$cells co-localize with collagen type I fibers (scale bar $=10 \mu \mathrm{m}$ ). D: FACS analysis performed on the same lungs revealed that most $\mathrm{CXCR}_{4}{ }^{+}$cells were positive for the donor antigen CD45.1 and were leukocytes $\left(\mathrm{CD} 45.1^{+} \mathrm{FSP}^{-}\right)$. A smaller fraction of donor CXCR ${ }^{+}$cells were fibrocytes (CD $45.1^{+} \mathrm{FSP}^{+}$or CD $45.1^{+} \mathrm{SMA}^{+}$cells). E: Collective data from FACS analysis of lungs from bleomycin-treated mice showed the reduced recruitment of CXCR4 ${ }^{+}$, $\mathrm{CD} 45.1^{+} / \mathrm{FSP}^{+}$in Sparc $^{-/-}$than WT counterparts without changing the proportion of fibrocytes within the FSP1 population $\left(24.6 \pm 9.6\right.$ in Sparc $^{-1-} ; 28.9 \pm 5.9$ in WT).
SPARC expression according to their donor origin (Figure 3A). Unexpectedly, bleomycin-induced lung damage, as assessed by histopathologic (Figure 3B) and IF analysis for collagen I and CD45 (Figure 3C), proved to be more severe in mice transplanted with Sparc ${ }^{-1-}$ than WT marrow. The most striking differences between these chimeras were in the inflammatory infiltration, the amount of collagen fibrosis, and the degree of the alveolar damage (see Supplemental Figure S5 at http://ajp.amjpathol.org). Collagen accumulation, evaluated as HP content, was higher in $\mathrm{KO}>\mathrm{WT}$ than in WT>WT chimeras (Figure 3D). The results of these BMT experiments indicate that more severe fibrosis occurred in $\mathrm{KO}>\mathrm{WT}$ chimeras despite the fibrocytes recruited into the lung, which were SPARC defective and thus incapable of collagen assembly. An interpretation of this finding was that host fibroblasts were sufficient to produce fibrosis in the context of exacerbated inflammation associated with the lack of SPARC in leukocytes. On these bases, we hypothesized that SPARC produced by leukocytes could have a role in regulating the inflammatory spur-triggering fibrosis.

This interpretation found confirmation in the reciprocal bone marrow chimeras obtained transplanting Sparc ${ }^{-1-}$ mice with WT or Sparc ${ }^{-1-}$ donors, a condition in which 
A

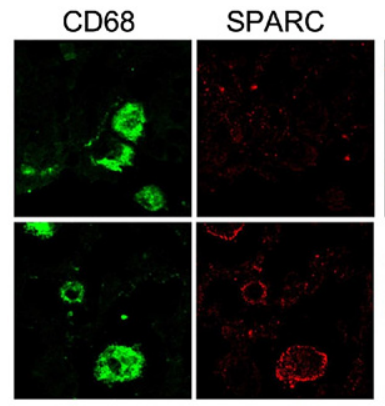

B

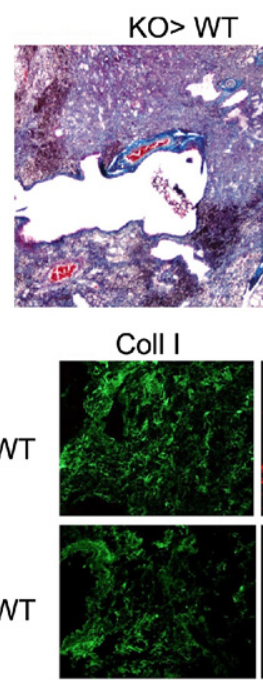

D

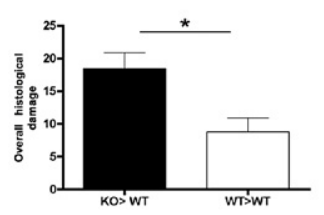

$\mathrm{KO}>\mathrm{WT}$

WT $>$ WT

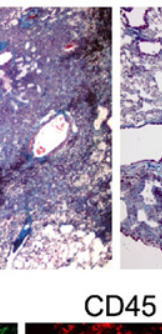

Merge

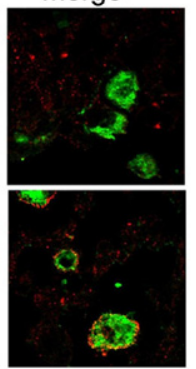

WT > WT

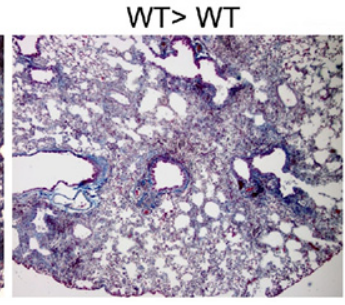

Merge
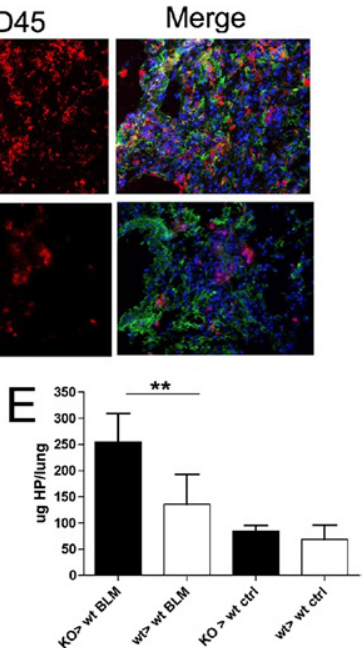

Figure 3. Increased inflammation and fibrosis in KO $>$ WT chimeras. A: Confocal microscopy for SPARC and CD68 shows SPARC expression in WT $>$ WT but not KO $>$ WT CD $68^{+}$macrophages, according to the genotype of donor cells. B: Trichrome staining of lungs from bleomycin-treated KO $>$ WT and WT $>$ WT bone marrow chimeras. Pictures are relative to one representative experiment of five performed with six mice per group (original magnification, $\times 200$ ). C: IF analysis of collagen type I (green signal) and CD45 (red signal) reveals increased collagen deposition and inflammatory infiltration in KO $>$ WT compared with WT $>$ WT chimeras. D: Overall histopathologic damage of bleomycin-treated bone marrow chimeras. The data are expressed as mean $\pm \mathrm{SD}(n=5)$ Bleomycin-treated KO>WT bone marrow chimera mice had significantly more lung damage than $\mathrm{KO}>\mathrm{KO}$ ones (Mann-Whitney $U$-test); ${ }^{*} P=0.0159$. E: Total HP contents in the lungs of $\mathrm{KO}>\mathrm{WT}$ and WT $>$ WT chimeras treated with bleomycin. Representative experiments of four performed with seven bleomycin-treated and four salinetreated chimeras. Mean $\pm \mathrm{SD}$ values are shown. Bleomycin-treated KO $>$ WT bone marrow chimeras mice had significantly more collagen than any other group (Mann-Whitney $U$-test); ${ }^{*} P=0.0079$.

host fibroblasts were impaired in collagen deposition, whereas the inflammatory spur was high or low, depending on donor SPARC genotype. Bleomycin-treatment of $\mathrm{KO}>\mathrm{KO}$ chimeras produced a more severe parenchymal inflammation and leukocyte infiltration than WT>KO chimeras, although significant fibrosis was absent (Figure $4 \mathrm{~A}$ ), a finding supported by immunostaining of lung sections for collagen type I and CD90 (lymphocytes), which highlights the scanty fibrosis and abundance of donor-

derived inflammatory cells (Figure 4B). Accordingly, the overall parenchymal damage score was significantly higher in $\mathrm{KO}>\mathrm{KO}$ than in WT>KO chimeras (Figure 4C; see also Supplemental Figure S6 at http://ajp.amjpathol. org), whereas the collagen content in lung was not significantly different (Figure 4D). These results, which are consistent with the impaired ECM deposition that characterizes Sparc ${ }^{-1-}$ mice, suggest that SPARC contribution to inflammation and fibrosis is distinct and oppositely influences the fibrotic outcome. Of note, in WT>KO combination, $\mathrm{CXCR} 4^{+} \mathrm{FSP} 1^{+}$fibrocytes of donor origin, although SPARC competent, were unable to mount significant fibrosis. This finding could be either because they were insufficient in number (see Supplemental Figure S7 at http://ajp.amjpathol.org) or because SPARC-competent leukocytes, also of donor origin, negatively control the extent of inflammation.

Overall, these experiments identified SPARC derived from bone marrow cells as endowed with anti-inflamma-
A

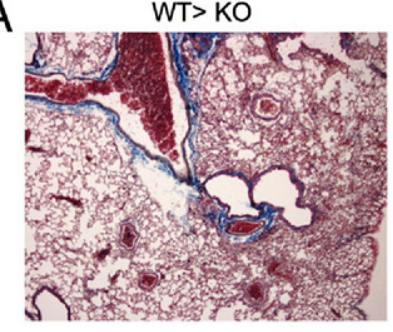

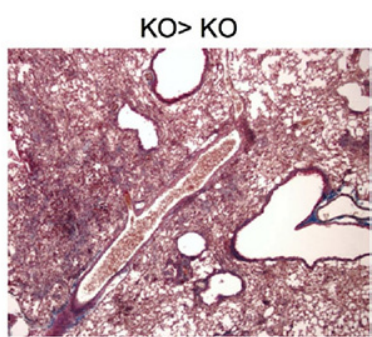

B

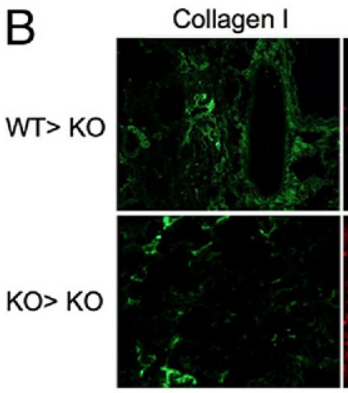

C

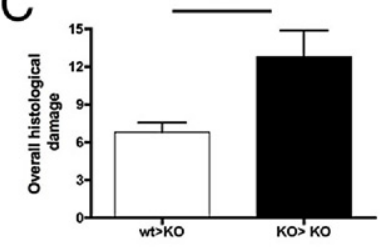

CD90

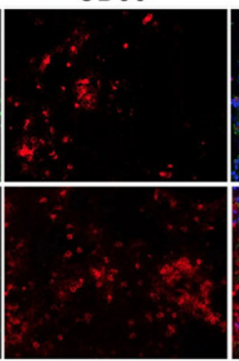

${ }^{150}{ }^{15} \quad$ n.s.

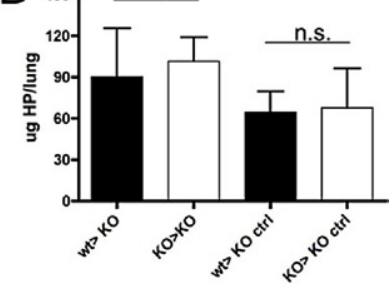

Figure 4. Fibrosis and inflammation are uncoupled in $\mathrm{KO}>\mathrm{KO}$ and WT $>$ KO chimeras. A: Trichrome staining of lungs from KO $>$ KO chimeras shows increased inflammatory infiltration but similar slight fibrosis compared with $\mathrm{WT}>\mathrm{KO}$ ones (original magnification, $\times 200$ ). Pictures are relative to one representative experiment of five performed with six mice per group. $\mathbf{B}$ : IF analysis of collagen type I (green signal) and CD90 (lymphocytes) supports comparable lung fibrosis but different inflammatory infiltration in the two types of chimeras. C: Overall histopathologic damage of bleomycintreated $\mathrm{WT}>\mathrm{KO}$ and $\mathrm{KO}>\mathrm{KO}$ bone marrow chimeras. The data are expressed as mean $\pm \mathrm{SD}(n=5)$. Bleomycin-treated $\mathrm{KO}>\mathrm{KO}$ chimeras mice had significantly more parenchymal damage than WT $>$ KO ones (MannWhitney $U$-test); ${ }^{* * *} P=0.0080$. D: Total HP contents in the lungs of WT $>$ KO and $\mathrm{KO}>\mathrm{KO}$ bone marrow chimeras treated with bleomycin. Representative experiments of four performed with seven bleomycin-treated and four salinetreated chimeras. Mean \pm SD values are shown. 
tory functions while confirming the requirement of SPARC, in-collagen secreting cells, as relevant toward fibrotic changes.

\section{Bone Marrow-Derived SPARC Regulates TNF Production}

Among the inflammatory molecules involved in fibrosis, TNF is a key cytokine in both humans and mice. The difference in bleomycin susceptibility between responder and nonresponder mouse strains has been correlated with their different production of TNF. ${ }^{27-30}$ We investigated whether an increase in TNF production was associated with the exacerbated bleomycin-induced fibrosis in $\mathrm{KO}>\mathrm{WT}$ chimeras. Indeed, TNF production was significantly higher in $\mathrm{KO}>\mathrm{WT}$ than in WT $>$ WT chimeras (Figure 5A), and IF analysis indicated that both $\mathrm{SP}_{-} \mathrm{C}^{+}$type II pneumocytes and CD11 $\mathrm{b}^{+}$leukocytes were responsible for TNF production (Figure 5B). The $\mathrm{KO}>\mathrm{WT}$ chimeras combined the severe inflammation, associated with Sparc ${ }^{-1-}$ bone marrow-derived cells, with the competence of host fibroblasts for collagen deposition. In such chimeras, we tested whether TNF neutralization could attenuate the excessive inflammatory spur engendered by Sparc $^{-1-}$ donors. KO>WT chimeras treated with monoclonal antibody-blocking TNF (clone V1q), but not those treated with control immunoglobulin isotype, showed milder inflammatory infiltration and, consequently, fibrosis (Figure 5, C-D; see also Supplemental Figure S8 at http://ajp.amjpathol.org).

\section{Persistent TNF Production in Sparc ${ }^{-1-}$ Bone Marrow Leukocytes Implies a Defective TGF- $\beta 1$ Regulatory Loop}

Considering that exacerbated inflammation depends on the Sparc ${ }^{-1-}$ genotype of bone marrow donors and on its association with increased TNF production, the relevant question is how SPARC could regulate TNF in leukocytes. TGF- $\beta 1$ is a potent profibrotic cytokine that stimulates collagen deposition and epithelial-mesenchymal transition, but at the same time it also has immunosuppressive $^{31}$ and anti-inflammatory ${ }^{32}$ properties. These features phenocopy those of SPARC in line with their cross-regulation. ${ }^{33}$ Thus, we tested whether Sparc ${ }^{-1-}$ bone marrow cells, prototypically macrophages, were less susceptible to TGF- $\beta 1$ in down-regulating TNF production, having checked their unimpaired capability to produce TGF- $\beta 1$ (see Supplemental Figure S9 at http://ajp.amjpathol.org). Macrophages were obtained from bone marrow precursors. WT but not Sparc ${ }^{-1-}$ macrophages showed decreased level of TNF in response to TGF- $\beta 1$ (Figure 6A). To extend this finding to the in vivo setting of bleomycininduced lung damage, we developed mice whose macrophages had been made insensitive to TGF- $\beta 1$ stimulation in the attempt to reproduce the phenotype of $\mathrm{KO}>\mathrm{WT}$ chimeras.

Mice were transplanted with bone marrow cells transduced to express a dominant negative form of TGF- $\beta$ RII, as decoy, under the monocyte-specific CD68 promoter.

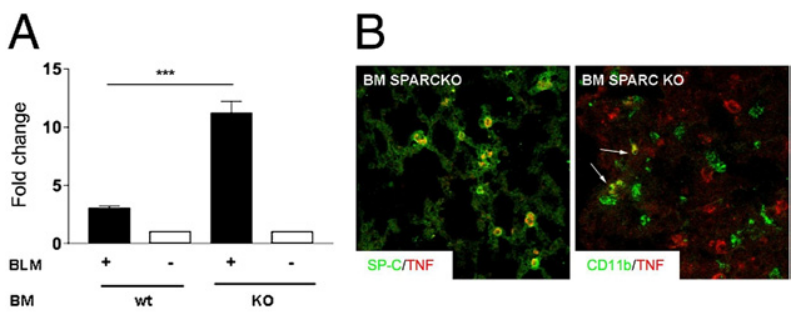

$\mathrm{C}_{\text {SPARC KO> WT }+\mathrm{Ctrl} A b}$

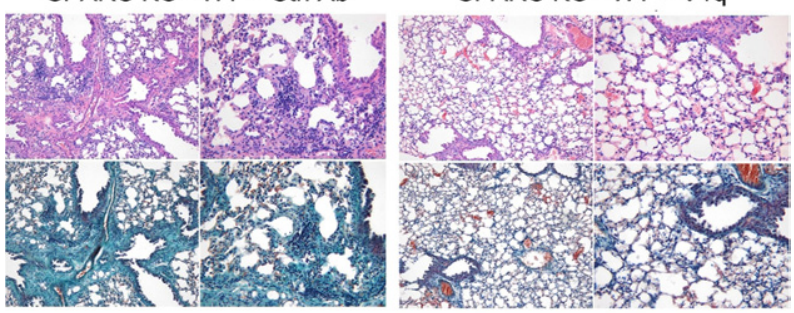

D

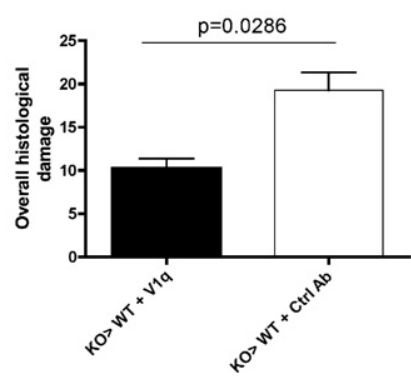

Figure 5. TNF production in SPARC KO $>$ WT and WT $>$ WT bone marrow chimeras. TNF content was evaluated in lungs obtained from bleomycin- or saline-treated KO $>$ WT or WT $>$ WT bone marrow chimeras. A: Western blot normalization (on $\beta$-actin as housekeeping gene) of TNF content, showing that the amount of TNF was increased in the lung of KO>WT bone marrow chimeras compared with WT $>$ WT ones. (One representative experiment of two performed with four replicates is shown; the data are expressed as mean \pm SD, Mann-Whitney $U$-test; ${ }^{* * * * *} P<0.001$.) B: IF analysis shows that in KO $>$ WT chimeras TNF (red signal) was expressed by type 2 pneumocytes $\left(\mathrm{SP}-\mathrm{C}+\right.$; green signal, left panel) and $\mathrm{CD}_{11} \mathrm{~b}^{+}$cells (green signal, right panel, arrows). C: Histopathologic analysis of the lungs of KO $>$ WT bone marrow chimeras treated with bleomycin in the presence or absence of the TNF blocking monoclonal antibody V1q. D: Overall histologic damage of V1q-treated versus control antibody-treated KO $>$ WT chimeras. Data are relative to one representative experiment ( $n=10$ per each experiment) of two performed. V1q treatment significantly reduced the overall histologic damage of bleomycin-treated KO $>$ WT bone marrow chimeras (Mann-Whitney $U$-test).

In these chimeras, inflammation and fibrosis were more conspicuous than in WT>WT counterparts while comparable to that of $\mathrm{KO}>\mathrm{WT}$ chimeras receiving bleomycin treatment (Figure 6B)

Altogether these results suggest that SPARC regulation of TGF- $\beta 1$ anti-inflammatory function on macrophages could be the mechanism responsible for sustaining exacerbated inflammation induced by Sparc $^{-1-}$ leukocytes.

\section{Discussion}

As a consequence of intense or chronic parenchymal damage, fibrosis compensates impaired tissue regeneration. This process, although unable to replace tissue or organ function (eg, myocardial scarring after infarction), 

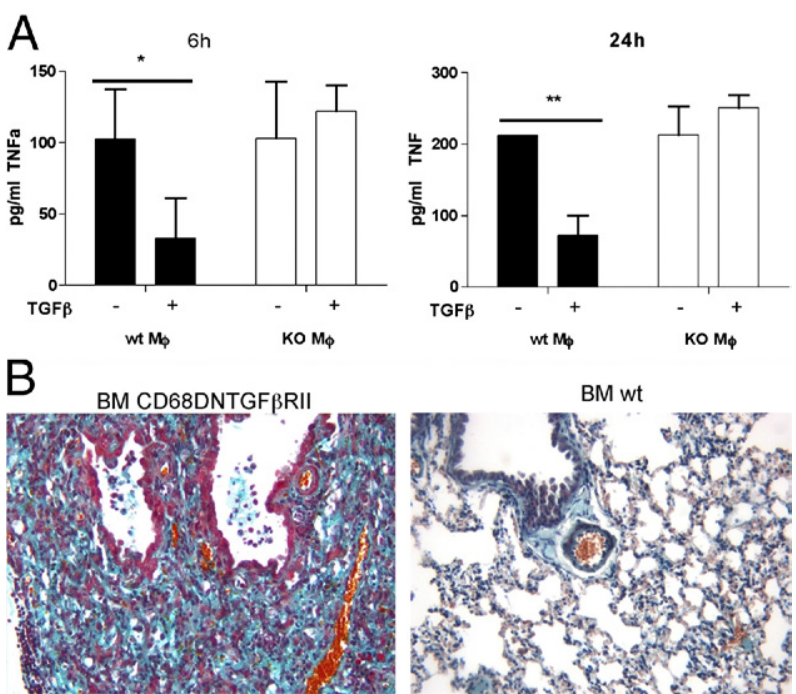

Figure 6. TNF and TGF- $\beta 1$ are reciprocally regulated in macrophages. A TGF- $\beta 1$ inhibition of TNF production by bone marrow-derived macrophages. Bone marrow-derived macrophages were seeded into a 96-well plate and treated with TGF- $\beta 1(10 \mathrm{ng} / \mathrm{mL})$ for 6 and 24 hours and evaluated for TNF production by enzyme-linked immunosorbent assay: TGF- $\beta 1$ significantly inhibited TNF production by WT but not Sparc $^{-1-}$ macrophages. One representative experiment of three performed is shown ( $n=6$ replicates for condition). ${ }^{*} P=0.0022 ;{ }^{* * *} P=0.0079$. B: Lung fibrosis and inflammation were greatly increased in WT mice transplanted with a bone marrow expressing the DN form of TGF- $\beta$ RII compared with WT mice receiving normal bone marrow. Lung damage in CD68DNTGF $\beta$ RII $>$ WT chimeras parallels that observed in KO $>$ WT mice. Data are relative to one representative experiment of two performed on a total of 10 mice

is in most cases controlled, and its regulation is strictly dependent on the resolution of the underlying inflammatory spur. SPARC is a matricellular glycoprotein involved in fibrosis ${ }^{3,4,7,34}$ through unknown mechanisms, in addition to its role in collagen and ECM deposition. ${ }^{35,36} \mathrm{An}$ impaired ECM deposition or the absence of SPARC is associated with increased inflammatory infiltration and immune cell migration. ${ }^{10,37,38}$ This finding has prompted the idea that SPARC might be involved in the regulation of inflammatory response as partially demonstrated in ovarian cancer, where SPARC normalizes the tumor microenvironment by regulating cytokine production. $^{12}$ In Sparc $^{-1-}$ mice inflammation is greater than in their WT counterparts. ${ }^{10}$ In the fibrotic process SPARC might play distinct roles in stroma remodeling and ECM deposition versus inflammation when produced by either fibroblasts or immune cells, respectively. To test whether such distinction exists in bleomycin-induced lung fibrosis, we combined the use of Sparc ${ }^{-1-}$ mice and BMT. We found that bone marrow-derived SPARC has a regulatory role on inflammation, whereas SPARC from lung fibroblasts sustains ECM deposition and fibrosis (Figure 7). The concurrent lack of SPARC in both bone marrow-derived and lung fibroblasts in nontransplanted Sparc $^{-1-}$ mice, as well as in $\mathrm{KO}>\mathrm{KO}$ chimeras, hindered lung fibrosis while augmenting inflammation when bleomycin was given. The impaired ECM deposition by Sparc ${ }^{-1-}$ collagen-producing cells, either resident or bone marrow derived, might have produced a condition unfavorable to fibrosis development. ${ }^{39,40}$ Because our scope was to dissect the role of SPARC produced by bone marrow-derived im- mune cells from the role of SPARC produced by stromal cells, the common bone marrow origin of fibrocytes and leukocytes required ad hoc BMT experiments to evaluate their relative contribution in fibrosis. We found that a portion of $\mathrm{FSP}{ }^{+}$cells in fibrotic lungs were $\mathrm{CXCR} 4^{+}$and $\mathrm{CD}_{4} 5^{+}$fibrocytes from a bone marrow donor. According to the literature, ${ }^{22}$ these cells account for $20 \%$ to $30 \%$ of the total FSP1 population and $3 \%$ to $6 \%$ of the total $\mathrm{CXCR}^{+}$cells recruited in the lung. We found these collagen-secreting cells, in the outcome of pulmonary fibro-
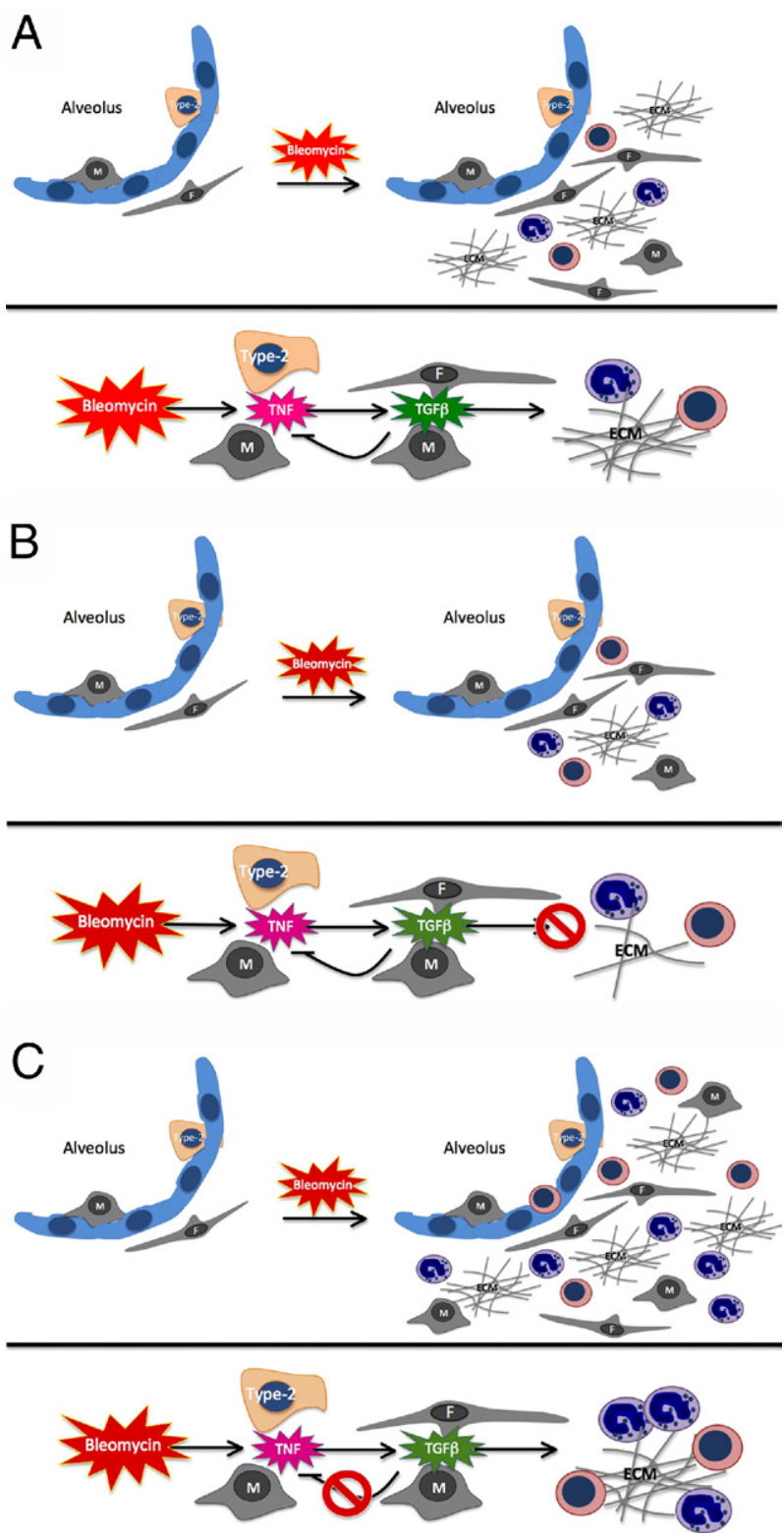

Figure 7. Schematic representation of the different contribution of host fibroblasts and leukocyte-derived SPARC to bleomycin-associated lung inflammation and fibrosis. A: In WT $>$ WT bone marrow chimeras, the administration of bleomycin induces inflammation and fibrosis through TNF synthesis that triggers TGF- $\beta$ release; TGF- $\beta$ promotes fibroblasts deposition and regulates TNF synthesis from macrophages. B: In WT $>$ SPARC KO chimeras, despite a normal parenchyma inflammation, collagen deposition by fibroblasts is greatly reduced and results in milder fibrosis. C: In SPARC KO >WT chimeras, the inability of SPARC KO macrophages to down-modulate TNF production in response to TGF- $\beta$ results in exaggerated and persistent inflammation and severe fibrosis 
sis, co-localizing with collagen fibers in WT but not Sparc ${ }^{-1-}$ mice. Yet, their role in the fibrotic process was marginal according to results in WT>KO chimeras that showed a mild fibrosis similar to that of $\mathrm{KO}>\mathrm{KO}$ mice despite the fact that Sparc ${ }^{-1-}$-competent fibrocytes were almost the main collagen-producing cells. The worst picture in terms of both inflammation and fibrosis was observed in KO> WT chimeras despite the fact that bone marrow-derived Sparc ${ }^{-1-}$ fibrocytes cannot contribute to collagen assembly. In the presence of adequate collagen secreting cells, the inflammatory spur was critical for the fibrotic outcome.

The high inflammatory infiltration, rich in T lymphocytes, which characterized the lungs of bleomycintreated Sparc ${ }^{-/-}$mice paralleled our previous finding showing accelerated dendritic cell migration and T-cell priming in the absence of SPARC, a notion that strengthens the role of ECM in the control of inflammation. ${ }^{10}$ Our findings of exacerbated inflammatory infiltration and high TNF production in the absence of fibrosis in the lungs of bleomycin-treated Sparc ${ }^{-1-}$ mice indicates that inflammation is necessary but not sufficient to induce fibrosis that also requires SPARC-competent collagen-secreting cells. ${ }^{41}$ The importance of TNF in lung fibrosis comes from both experimental mouse models and human data. The risk of chemotherapy-induced pulmonary fibrosis has been associated with a polymorphism into the TNF $\alpha 2$ gene and increased TNF production. ${ }^{30}$ Also in mice, the relative resistance of the BALB/c strain to develop fibrosis after bleomycin instillation has been associated with impaired TNF production and its p75 receptor up-regulation $^{28,29}$ rather than to a reduced modulation of TGF- $\beta$ RI and TGF- $\beta$ RII ${ }^{42,43}$

Soluble, rather than transmembrane, TNF is required for developing fibrotic lesions via lymphocyte recruitment and their production of TGF- $\beta 1$. Kapancy and colleagues were the first to localize TNF stored in type II alveolar pneumocytes and to postulate the need for epithelialmesenchymal cross-talk involving TNF and TGF- $\beta 1$ toward fibrosis development. ${ }^{44}$

SPARC has been described to regulate TGF- $\beta 1$ signaling by binding to its receptor. ${ }^{45,46}$ In light of the combined effect of TGF- $\beta 1$ in inducing fibrosis but also in regulating inflammatory responses, ${ }^{31,47}$ we reasoned that the contrasting roles of SPARC in the setting of lung fibrosis might be explained by its capability to affect TGF- $\beta 1$ functions. Accordingly, SPARC absence from fibroblasts resulted in impaired collagen fibrosis, whereas its deficiency in leukocytes resulted in exacerbated inflammation owing to impaired TGF- $\beta 1$-mediated TNF down-modulation. Indeed, macrophages from WT but not from Sparc ${ }^{-1-}$ mice treated in vitro with TGF- $\beta 1$ were inhibited for TNF release. The impaired resolution of the inflammatory spur in KO $>$ WT chimeras might be responsible, at least in part, for the worsened fibrosis. The persistent TNF production, in the case of Sparc ${ }^{-1-}$ bone marrow leukocytes, could be explained by SPARC attenuating NF- $\kappa \mathrm{B}$ signaling as described in ovarian cancer. ${ }^{12}$

In fibroblasts, TNF promotes TGF- $\beta 1$ expression via AP-1 activation, ${ }^{48}$ which also controls SPARC expression. ${ }^{49}$ The similarity between SPARC and TGF- $\beta 1$ suggests their dual effect on leukocyte and fibroblasts, reducing inflammation and promoting fibrogenesis, respectively.

Considering the disappointing results obtained using corticosteroids in the treatment of lung fibrosis, ${ }^{50}$ TNF emerges as an appealing target. In humans, TNF inhibition by infliximab seems to stabilize the progression of pulmonary fibrosis associated with collagen vascular disease in patients with rheumatoid arthritis and systemic sclerosis. ${ }^{51-53}$ In our mouse model, TNF inhibition halted the progression of fibrosis in the highly susceptible KO $>$ WT chimeras. It is likely that TNF might be important in establishing fibrosis, whereas other factors, such as connective tissue growth factor, platelet-derived growth factor, and IL-13, would amplify and consolidate the pathological process. ${ }^{54}$ Two studies have so far evaluated the role of SPARC in bleomycin-induced fibrosis with opposite conclusions on the role of SPARC in such setting. One such study reported increased fibrosis in Sparc $^{-1-}$ mice because of exacerbated leukocyte recruitment and inflammation, ${ }^{9}$ whereas the other showed a milder fibrosis because of the reduced ECM deposition occurring in Sparc ${ }^{-1-}$ mice. ${ }^{6}$ Our study, while confirming the exacerbated inflammation of the former study, excludes the increase of fibrosis in Sparc ${ }^{-1-}$ mice and agrees with the latter concerning the reduced collagen deposition associated with Sparc deficiency, supporting the notion that both inflammation and collagen deposition are oppositely regulated by SPARC. In conclusion, the dual role of SPARC in bleomycin-induced lung fibrosis delineated in this report might be envisaged for other settings in which fibrosis follows an unhealed inflammatory spur, such as in liver and kidney fibrosis.

\section{References}

1. Kos K, Wilding JP: SPARC: a key player in the pathologies associated with obesity and diabetes. Nat Rev Endocrinol 2010, 6:225-235

2. Nakatani K, Seki S, Kawada N, Kitada T, Yamada T, Sakaguchi H, Kadoya H, Ikeda K, Kaneda K: Expression of SPARC by activated hepatic stellate cells and its correlation with the stages of fibrogenesis in human chronic hepatitis. Virchows Arch 2002, 441:466-474

3. Frizell E, Liu SL, Abraham A, Ozaki I, Eghbali M, Sage EH, Zern MA Expression of SPARC in normal and fibrotic livers. Hepatology 1995 21:847-854

4. Demopoulos K, Arvanitis DA, Vassilakis DA, Siafakas NM, Spandidos DA: MYCL1. FHIT, SPARC, p16(INK4) and TP53 genes associated to lung cancer in idiopathic pulmonary fibrosis. J Cell Mol Med 2002, 6:215-222

5. Zhou X, Tan FK, Guo X, Arnett FC: Attenuation of collagen production with small interfering RNA of SPARC in cultured fibroblasts from the skin of patients with scleroderma. Arthritis Rheum 2006, 54:26262631

6. Strandjord TP, Madtes DK, Weiss DJ, Sage EH: Collagen accumulation is decreased in SPARC-null mice with bleomycin-induced pulmonary fibrosis. Am J Physiol 1999, 277:L628-L635

7. Camino AM, Atorrasagasti C, Maccio D, Prada F, Salvatierra E, Rizzo M, Alaniz L, Aquino JB, Podhajcer OL, Silva M, Mazzolini G: Adenovirus-mediated inhibition of SPARC attenuates liver fibrosis in rats. J Gene Med 2008, 10:993-1004

8. Wang JC, Lai S, Guo X, Zhang X, de Crombrugghe B, Sonnylal S Arnett FC, Zhou $X$ : Attenuation of fibrosis in vitro and in vivo with SPARC siRNA. Arthritis Res Ther 2010, 12:R60

9. Savani RC, Zhou Z, Arguiri E, Wang S, Vu D, Howe CC, DeLisser HM Bleomycin-induced pulmonary injury in mice deficient in SPARC Am J Physiol Lung Cell Mol Physiol 2000, 279:L743-L750 
10. Sangaletti S, Gioiosa L, Guiducci C, Rotta G, Rescigno M, Stoppacciaro A, Chiodoni C, Colombo MP: Accelerated dendritic-cell migration and T-cell priming in SPARC-deficient mice. J Cell Sci 2005, 118:3685-3694

11. Sangaletti S, Stoppacciaro A, Guiducci C, Torrisi MR, Colombo MP: Leukocyte, rather than tumor-produced SPARC, determines stroma and collagen type IV deposition in mammary carcinoma. J Exp Med 2003, 198:1475-1485

12. Said NA, Elmarakby AA, Imig JD, Fulton DJ, Motamed K: SPARC ameliorates ovarian cancer-associated inflammation. Neoplasia 2008, 10:1092-1104

13. Sleijfer S: Bleomycin-induced pneumonitis. Chest 2001, 120:617-624

14. Regnier M, Delescluse C, Prunieras M: Studies on guinea pig skin cell cultures. I: separate cultures of keratinocytes and dermal fibroblasts. Acta Derm Venereol 1973, 53:241-247

15. Oliver MH, Harrison NK, Bishop JE, Cole PJ, Laurent GJ: A rapid and convenient assay for counting cells cultured in microwell plates: application for assessment of growth factors. J Cell Sci 1989, 92(pt 3): 513-518

16. Colombo MP, Lombardi L, Stoppacciaro A, Melani C, Parenza M, Bottazzi B, Parmiani G: Granulocyte colony-stimulating factor (GCSF) gene transduction in murine adenocarcinoma drives neutrophilmediated tumor inhibition in vivo: neutrophils discriminate between G-CSF-producing and G-CSF-nonproducing tumor cells/ J Immunol 1992, 149:113-119

17. Sangaletti S, Di Carlo E, Gariboldi S, Miotti S, Cappetti B, Parenza M, Rumio C, Brekken RA, Chiodoni C, Colombo MP: Macrophage-derived SPARC bridges tumor cell-extracellular matrix interactions toward metastasis. Cancer Res 2008, 68:9050-9059

18. Kivirikko KI, Laitinen O, Prockop DJ: Modifications of a specific assay for hydroxyproline in urine. Anal Biochem 1967, 19:249-255

19. Baker JR, Rosenkrantz H: Volumetric instillation of fixatives and inert substances into mouse lungs. Stain Technol 1976, 51:107-113

20. Wynn TA: Integrating mechanisms of pulmonary fibrosis. J Exp Med 2011, 208:1339-1350

21. Moore BB, Kolodsick JE, Thannickal VJ, Cooke K, Moore TA, Hogaboam C, Wilke CA, Toews GB: CCR2-mediated recruitment of fibrocytes to the alveolar space after fibrotic injury. Am J Pathol 2005, 166:675-684

22. Kisseleva T, Brenner DA: Mechanisms of fibrogenesis. Exp Biol Med (Maywood) 2008, 233:109-122

23. Lawson WE, Polosukhin VV, Zoia O, Stathopoulos GT, Han W, Plieth D, Loyd JE, Neilson EG, Blackwell TS: Characterization of fibroblastspecific protein 1 in pulmonary fibrosis. Am J Respir Crit Care Med 2005, 171:899-907

24. Tripodo C, Sangaletti S, Piccaluga PP, Prakash S, Franco G, Borrello I, Orazi A, Colombo MP, Pileri SA: The bone marrow stroma in hematological neoplasms-a guilty bystander. Nat Rev Clin Oncol 2011, 8:456-466

25. Ishida Y, Kubota H, Yamamoto A, Kitamura A, Bachinger HP, Nagata $\mathrm{K}$ : Type I collagen in Hsp47-null cells is aggregated in endoplasmic reticulum and deficient in $\mathrm{N}$-propeptide processing and fibrillogenesis. Mol Biol Cell 2006, 17:2346-2355

26. Bradshaw AD: The role of SPARC in extracellular matrix assembly. J Cell Commun Signal 2009, 3:239-246

27. Phan SH, Kunkel SL: Lung cytokine production in bleomycin-induced pulmonary fibrosis. Exp Lung Res 1992, 18:29-43

28. Ortiz LA, Lasky J, Hamilton RF, Jr., Holian A, Hoyle GW, Banks W, Peschon JJ, Brody AR, Lungarella G, Friedman M: Expression of TNF and the necessity of TNF receptors in bleomycin-induced lung injury in mice. Exp Lung Res 1998, 24:721-743

29. Ortiz LA, Moroz K, Liu JY, Hoyle GW, Hammond T, Hamilton RF, Holian A, Banks W, Brody AR, Friedman M: Alveolar macrophage apoptosis and TNF-alpha, but not p53, expression correlate with murine response to bleomycin. Am J Physiol 1998, 275:L1208-L1218

30. Libura J, Bettens F, Radkowski A, Tiercy JM, Piguet PF: Risk of chemotherapy-induced pulmonary fibrosis is associated with polymorphic tumour necrosis factor-a2 gene. Eur Respir J 2002, 19:912-918

31. Yoshimura A, Muto G: TGF-beta function in immune suppression. Curr Top Microbiol Immunol 2011, 350:127-147

32. Yoshimura A, Wakabayashi Y, Mori T: Cellular and molecular basis for the regulation of inflammation by TGF-beta. J Biochem 2010, 147: 781-792
33. Schellings MW, Vanhoutte D, Swinnen M, Cleutjens JP, Debets J, van Leeuwen RE, D'Hooge J, Van de Werf F, Carmeliet P, Pinto YM, Sage $\mathrm{EH}$, Heymans S: Absence of SPARC results in increased cardiac rupture and dysfunction after acute myocardial infarction. J Exp Med 2009, 206:113-123

34. Chang W, Wei K, Jacobs SS, Upadhyay D, Weill D, Rosen GD: SPARC suppresses apoptosis of IPF fibroblasts through constitutive activation of beta-catenin. J Biol Chem 2010, 285:8196-206

35. Bradshaw AD, Sage EH: SPARC, a matricellular protein that functions in cellular differentiation and tissue response to injury. J Clin Invest 2001, 107:1049-1054

36. Sangaletti S, Colombo MP: Matricellular proteins at the crossroad of inflammation and cancer. Cancer Lett 2008, 267:245-253

37. Alvarez MJ, Prada F, Salvatierra E, Bravo Al, Lutzky VP, Carbone C, Pitossi FJ, Chuluyan HE, Podhajcer OL: Secreted protein acidic and rich in cysteine produced by human melanoma cells modulates polymorphonuclear leukocyte recruitment and antitumor cytotoxic capacity. Cancer Res 2005, 65:5123-5132

38. Chiodoni C, Colombo MP, Sangaletti S: Matricellular proteins: from homeostasis to inflammation, cancer, and metastasis. Cancer Metastasis Rev 2010, 29:295-307

39. Strieter RM, Keeley EC, Hughes MA, Burdick MD, Mehrad B: The role of circulating mesenchymal progenitor cells (fibrocytes) in the pathogenesis of pulmonary fibrosis. J Leukoc Biol 2009, 86:1111-1118

40. Bellini A, Mattoli S: The role of the fibrocyte, a bone marrow-derived mesenchymal progenitor, in reactive and reparative fibroses. Lab Invest 2007, 87:858-870

41. Selman M, Pardo A: Idiopathic pulmonary fibrosis: an epithelial/fibroblastic cross-talk disorder. Respir Res 2002, 3:3

42. Cavarra E, Carraro F, Fineschi S, Naldini A, Bartalesi B, Pucci A, Lungarella G: Early response to bleomycin is characterized by different cytokine and cytokine receptor profiles in lungs. Am J Physiol Lung Cell Mol Physiol 2004, 287:L1186-L1192

43. Kolb M, Bonniaud P, Galt T, Sime PJ, Kelly MM, Margetts PJ, Gauldie $\mathrm{J}$ : Differences in the fibrogenic response after transfer of active transforming growth factor-beta1 gene to lungs of "fibrosis-prone" and "fibrosis-resistant" mouse strains. Am J Respir Cell Mol Biol 2002, 27:141-150

44. Kapanci Y, Desmouliere A, Pache JC, Redard M, Gabbiani G: Cytoskeletal protein modulation in pulmonary alveolar myofibroblasts during idiopathic pulmonary fibrosis. Possible role of transforming growth factor beta and tumor necrosis factor alpha. Am J Respir Crit Care Med 1995, 152:2163-2169

45. Francki A, Bradshaw AD, Bassuk JA, Howe CC, Couser WG, Sage $\mathrm{EH}$ : SPARC regulates the expression of collagen type I and transforming growth factor-beta1 in mesangial cells. J Biol Chem 1999, 274:32145-32152

46. Francki A, McClure TD, Brekken RA, Motamed K, Murri C, Wang T, Sage EH: SPARC regulates TGF-beta1-dependent signaling in primary glomerular mesangial cells. J Cell Biochem 2004, 91:915-925

47. Imai K, Takeshita A, Hanazawa S: Transforming growth factor-beta inhibits lipopolysaccharide-stimulated expression of inflammatory cytokines in mouse macrophages through downregulation of activation protein 1 and CD14 receptor expression. Infect Immun 2000, 68: $2418-2423$

48. Sullivan DE, Ferris M, Nguyen H, Abboud E, Brody AR: TNF-alpha induces TGF-beta1 expression in lung fibroblasts at the transcriptional level via AP-1 activation. J Cell Mol Med 2009, 13:1866-1876

49. Vial E, Perez S, Castellazzi M: Transcriptional control of SPARC by $\mathrm{v}$-Jun and other members of the AP1 family of transcription factors. Oncogene 2000, 19:5020-5029

50. Mapel DW, Samet JM, Coultas DB: Corticosteroids and the treatment of idiopathic pulmonary fibrosis: past, present, and future. Chest 1996, 110:1058-1067

51. Antoniou KM, Mamoulaki M, Malagari K, Kritikos HD, Bouros D, Siafakas NM, Boumpas DT: Infliximab therapy in pulmonary fibrosis associated with collagen vascular disease. Clin Exp Rheumatol 2007, 25:23-28

52. Bargagli $E$, Galeazzi $M$, Rottoli P: Infliximab treatment in a patient with rheumatoid arthritis and pulmonary fibrosis. Eur Respir J 2004, 24:708

53. Vassallo R, Matteson E, Thomas CF, Jr.: Clinical response of rheumatoid arthritis-associated pulmonary fibrosis to tumor necrosis factor-alpha inhibition Chest 2002, 122:1093-1096

54. Scotton CJ, Chambers RC: Molecular targets in pulmonary fibrosis: the myofibroblast in focus. Chest 2007, 132:1311-1321 